\title{
Effectiveness of Secondary Alveolar Bone Graft on Canine Eruption: Systematic Review
}

\author{
Rogério Lacerda-Santos ${ }^{1, \odot}$ Rhaslla Gonçalves Batista ${ }^{1}$ Samantha Silva Neves ${ }^{1}$ \\ José Lucas dos Santos Araújo ${ }^{2}$ Rayssa Amaral Vieira ${ }^{2}$ Fabiola Galbiatti de Carvalho ${ }^{1}$ \\ Matheus Melo Pithon ${ }^{3}$ Carolina de Castro Martins ${ }^{4}$
}

\author{
${ }^{1}$ Department of Orthodontics and Pediatric Dentistry, Faculty of \\ Dentistry, Federal University of de Fora, Governador Valadares, \\ Minas Gerais, Brazil \\ 2Department Orthodontics and Pediatric Dentistry, Dental School, \\ Federal University of Juiz de Fora, Juiz de Fora, Minas Gerais, Brazil \\ ${ }^{3}$ Department of Orthodontics, State University of the Southwest of \\ Bahia, Jéquie, Bahia, Brazil \\ ${ }^{4}$ Department of Pediatric Dentistry Dental School, Federal \\ University of Minas Gerais, Belo Horizonte, Minas Gerais, Brazil
}

\begin{abstract}
Address for correspondence Rogério Lacerda-Santos, DDS, MSD, $\mathrm{PhD}$, Federal University of Juiz de Fora, Department of Orthodontics, Faculty of Dentistry, Avenue Doutor Raimundo Monteiro Rezende, n.330, Centro, 35010-177 Governador Valadares, Minas Gerais, Brazil (e-mail: lacerdaorto@hotmail.com; lacerdaorto@gmail.com).
\end{abstract}

Eur J Dent 2021;15:579-587

\begin{abstract}
Keywords

- cleft palate

- alveolar bone grafting

- tooth eruption

- systematic review

There are controversies related to the effects of bone grafts on tooth eruption and impaction in patients with cleft lip and palate. The aim of this systematic review was to evaluate the effectiveness of bone grafting on eruption of canines in patients with unilateral cleft lip and palate (UCLP). An electronic search was conducted in six electronic databases and gray literature, without limitations on year of publication or language. The primary outcome was the increase in rate of canine eruption; the secondary outcomes were success of the bone graft, canine impaction due to agenesis of the lateral incisor, and effect of orthodontic treatment before and after bone grafting. The risk of bias was analyzed by means of the tool Cochrane risk of bias in nonrandomized controlled trials (NRCTs) of interventions (ROBINS-I). The certainty of the evidence was assessed for outcomes reported through a narrative synthesis using grading of recommendations, assessment, development and evaluation (GRADE) approach. Four NRCTs were included, with a total of 360 patients, 283 UCLP and 77 bilateral cleft lip and palate (BCLP). The studies reported association between the increase in the rate of tooth eruption and bone graft with very low certainty of evidence, and greater experience of surgical success, with low certainty of evidence. The majority of the studies found an association between increase in the rate of canine impaction and agenesis of the lateral incisor, with very low certainty of evidence. There was very low certainty of the efficacy of secondary alveolar bone grafting for increasing the rates of eruption and reducing impaction of the maxillary canine.
\end{abstract}

\section{Introduction}

Cleft lip with or without cleft palate and cleft palate are common craniofacial deformities in human beings. ${ }^{1}$ Patients with clefts involving the palate generally need bone grafts at different stages of life, in order to re-establish the growth and

published online

February 23, 2021
DOI https://doi.org/

$10.1055 / \mathrm{s}-0041-1723070$ ISSN $1305-7456$. development of the face and allow the evolution of normal occlusion, ${ }^{2}$ especially the canines commonly involved in the morphogenesis of cleft palate. ${ }^{3}$

Among these grafts, the primary type is used before patients complete 1 year of age; the early secondary type is performed before eruption of the permanent canine,

(c) 2021. European Journal of Dentistry.

This is an open access article published by Thieme under the terms of the Creative Commons Attribution-NonDerivative-NonCommercial-License, permitting copying and reproduction so long as the original work is given appropriate credit. Contents may not be used for commercial purposes, or adapted, remixed, transformed or built upon. (https://creativecommons.org/licenses/by-nc-nd/4.0/).

Thieme Medical and Scientific Publishers Pvt. Ltd. A-12, 2nd Floor, Sector 2, Noida-201301 UP, India 
and the late secondary, after eruption of the permanent canine., ${ }^{3,4}$ Successful bone grafting has been related to the patient's age at the time of surgery, gender, stage of eruption of permanent canine adjacent to the cleft, size of cleft, development of postoperative infection, and orthodontic treatment. ${ }^{2,5,6}$

Pre and postsurgery orthodontic treatment may play an important role in allowing space in the dental arch for the requirements of the graft and for suiting the teeth in the rehabilitation of patients with clefts. ${ }^{2,7,8}$ Some studies ${ }^{9,10}$ have reported that secondary bone grafting may increase the intraosseous retention of the maxillary canines, while others ${ }^{11,12}$ have demonstrated that the bone graft works as a guide for the eruption of these teeth. $3,7,13,14$

In conjunction, the literature has shown controversies in relation to the real effects of bone grafting, and its influence on eruption of the canine in adolescent patients with clefts. ${ }^{3,711-14}$ In view of the absence of systematic reviews about the topic up to now, the aim of the authors of this review was to evaluate the body of scientific evidence of the efficacy of secondary alveolar bone grafting on eruption of the permanent canine in patients with clefts.

\section{Materials and Methods}

\section{Focus Question}

This systematic review was conducted in order to answer the following clinical question: Is there any scientific evidence of the efficacy of secondary alveolar bone graft surgery has in patients with unilateral clefts for increasing the rate of eruption of the maxillary canine in the cleft area when compared with the control or to patients who were not submitted to surgery? The population, intervention, control, and outcomes (PICO) question and eligibility criteria are detailed in

\section{- Table 1.}

This systematic review was conducted in accordance with the items of reference for the evaluation of articles in systematic reviews and meta-analysis (preferred reporting items for systematic review and meta-analysis [PRISMA]). ${ }^{15}$

\section{Search Strategy}

An electronic search was conducted in the following databases up until November 2020, without limitation on year of publication or language: PubMed (Medline), Scopus, Web of Science, Medline Complete (EBSCO), Cochrane (Database for Systematic Review, CENTRAL, and Protocols), and gray literature through Trials Central and Clinical Trials. A manual search was conducted in specific periodicals of the area (The Cleft Palate-Craniofacial Journal, Plastic and Reconstructive Surgery) and in the list of references of the articles selected. ${ }^{15,16}$ The search strategies are described in - Table 2 .

\section{Eligibility Criteria of the Articles}

Two researchers (R.G.B. and R.L.S.) independently selected the abstracts, titles and complete texts, according to the eligibility criteria (-Table 1). Discrepancies were decided
Table 1 Criteria (PICOS, inclusion and exclusion) for selecting the studies

\begin{tabular}{|c|c|c|}
\hline \multicolumn{3}{|l|}{ PICOS } \\
\hline Participant (P) & \multicolumn{2}{|c|}{$\begin{array}{l}\text { Patients with cleft lip and palate, and mean } \\
\text { age between } 7 \text { and } 14 \text { years }\end{array}$} \\
\hline Intervention (I) & \multicolumn{2}{|c|}{$\begin{array}{l}\text { Secondary alveolar graft surgery in the cleft } \\
\text { region }\end{array}$} \\
\hline Comparison (C) & \multicolumn{2}{|c|}{ Not submitted to surgery } \\
\hline \multirow[t]{2}{*}{ Outcomes (O) } & $\begin{array}{l}\text { Primary } \\
\text { outcome: }\end{array}$ & $\begin{array}{l}\text { Increased rate of canine } \\
\text { eruption }\end{array}$ \\
\hline & $\begin{array}{l}\text { Secondary } \\
\text { outcome: }\end{array}$ & $\begin{array}{l}\text { Successful bone graft } \\
\text { Canine impacted due to agene- } \\
\text { sis of the lateral incisor. } \\
\text { Effect of orthodontic treatment } \\
\text { before and after bone graft } \\
\text { surgery }\end{array}$ \\
\hline Study (S) & \multicolumn{2}{|c|}{ Nonrandomized controlled trials (NRCTs) } \\
\hline \multicolumn{3}{|l|}{ Criteria } \\
\hline Inclusion & \multicolumn{2}{|c|}{$\begin{array}{l}\text { Report the dental condition, canine eruption } \\
\text { and impaction, presence of agenesis and } \\
\text { orthodontic treatment indication of patients } \\
\text { with unilateral cleft lip and palate, who } \\
\text { received secondary bone graft before eruption } \\
\text { of the canine. }\end{array}$} \\
\hline Exclusion & \multicolumn{2}{|c|}{$\begin{array}{l}\text { Patients making use of systemic medication } \\
\text { and those with systemic diseases. Patients who } \\
\text { have not received bone graft prior to eruption } \\
\text { of canine, who did not have eruption of canine } \\
\text { evaluated, considering its intraosseous angu- } \\
\text { lation/position. Studies reporting bone graft } \\
\text { with history of trauma or fistulas. Case reports, } \\
\text { case series, studies with number of participants } \\
<65 \text {, studies with animals, corticotomy, osteo- } \\
\text { genic distraction, in vitro studies, reviews of the } \\
\text { literature and editorials. }\end{array}$} \\
\hline
\end{tabular}

by discussion and consensus. ${ }^{17}$ In the event of divergences between the two evaluators, who could not reach consensus, a third evaluator (S.S.N.) was consulted.

\section{Quality and Risk of Bias Assessment}

Two independent reviewers evaluated the risk of bias of the studies included by using the Cochrane risk of bias in nonrandomized controlled trials (NRCTs) of interventions (ROBINS-I) guidelines. ${ }^{18}$

The domains evaluated by ROBINS-I were: (1) bias due to a confusion; (2) bias in selection of the study participants; (3) bias in classification of the interventions; (4) bias due to deviations from the intended intervention; (5) bias due to lack of data; (6) bias in measurement of the results; (7) bias in selection of the result reported. The general risk of bias of the individual studies was classified as being low (if all the domains were considered to have low risk of bias), moderate (if one or more domains showed moderate risk of bias), serious (if one or more domains showed serious risk of bias), or critical (if one or more domains showed critical risk of bias).

\section{Data Extraction and Data Analysis}

Two independent reviewers extracted data. Disagreements were solved by discussion until a consensus was reached. 
Table 2 Database and research method

\begin{tabular}{|c|c|}
\hline Database & Search Strategy \\
\hline $\begin{array}{l}\text { Pubmed (Medline) } \\
\text { Web of Science (Clarivate Analytics) } \\
\text { Medline Complete (EBSCO) } \\
\text { Cochrane (Database for Systematic } \\
\text { Reviews, CENTRAL, Trials, } \\
\text { Protocols) }\end{array}$ & 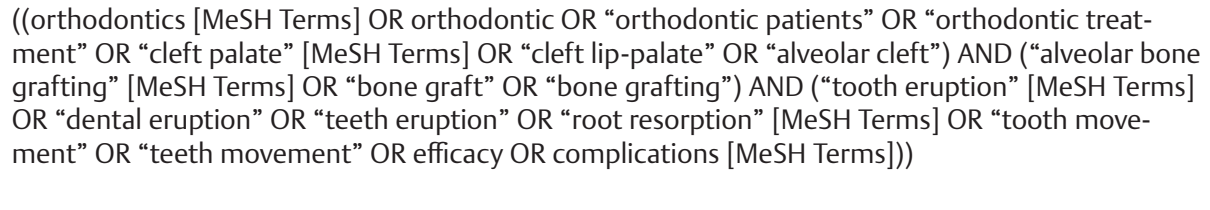 \\
\hline Scopus (Elsevier) & 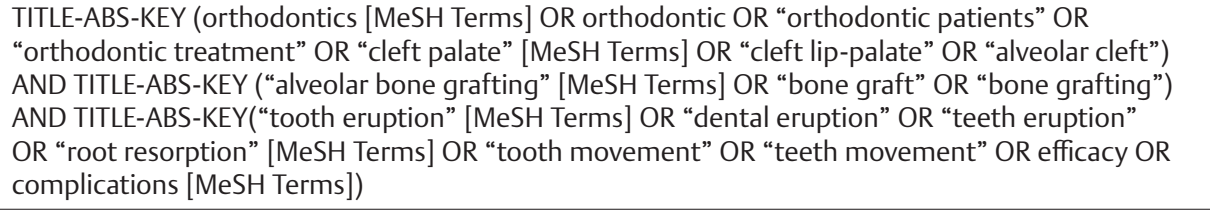 \\
\hline Trials Central & ((orthodontics [MeSH Terms])) \\
\hline Clinical Trials & ((orthodontics [MeSH Terms]) AND (alveolarbonegrafting [MeSH Terms] OR bone grafta)) \\
\hline
\end{tabular}

The primary outcome was increase in the rate of canine eruption. The secondary outcomes were success of bone graft, canine impaction due to agenesis of the lateral incisor, and effect of orthodontic treatment before and after bone grafting.

The was a high level of heterogeneity in data reported by studies, thus it was not possible to pool data for a meta-analysis. A narrative synthesis was planned instead. For reporting the outcomes, a summary of findings (SoF) table was built for each outcome according to grading of recommendations, assessment, development and evaluation (GRADE) pro. We followed the GRADE approach when using ROBINS-I to assess the certainty of the evidence for narrative synthesis. ${ }^{19,20}$ Using ROBINS-I, the certainty of the evidence began with high, and it could be further rated up by magnitude of the effect, dose response, and effect of residual confounders. ${ }^{20}$

\section{Results}

\section{Selection of Studies}

After triage of the titles and abstracts of 750 articles, 66 potentially eligible articles were selected for full text analysis; of these, 04 NRCTs., ${ }^{3,13,14}$ were included (-Fig. 1). RCTs were not found for the addressed criteria. The characteristics of studies are described in - Table $\mathbf{3}$ and the outcomes in - Table 4.

\section{Characteristics of Studies}

The studies evaluated a total of 360 patients, of whom 283 patients had unilateral cleft lip and palate (UCLP) and 77 had bilateral cleft lip and palate (BCLP), with mean age ranging between 7 and 13.7 years. The studies were conducted between 2007 and 2018 in Canada, ${ }^{3}$ Brazil, ${ }^{7}$ Italy, ${ }^{13}$ and Sweden. ${ }^{14}$

All the studies ${ }^{3,7,13,14}$ evaluated the position of the vertical angulation of the canine, one ${ }^{13}$ study evaluated the long axis of the canine in relation to the occlusal plane, two $^{3,14}$ evaluated it in relation to the median sagittal plane, and the other, ${ }^{7}$ in relation to the bicondylar line. The lateral position of the canine in relation to the lateral incisor was evaluated by only one ${ }^{3}$ study, and its height, in relation to the occlusal plane by the other study.

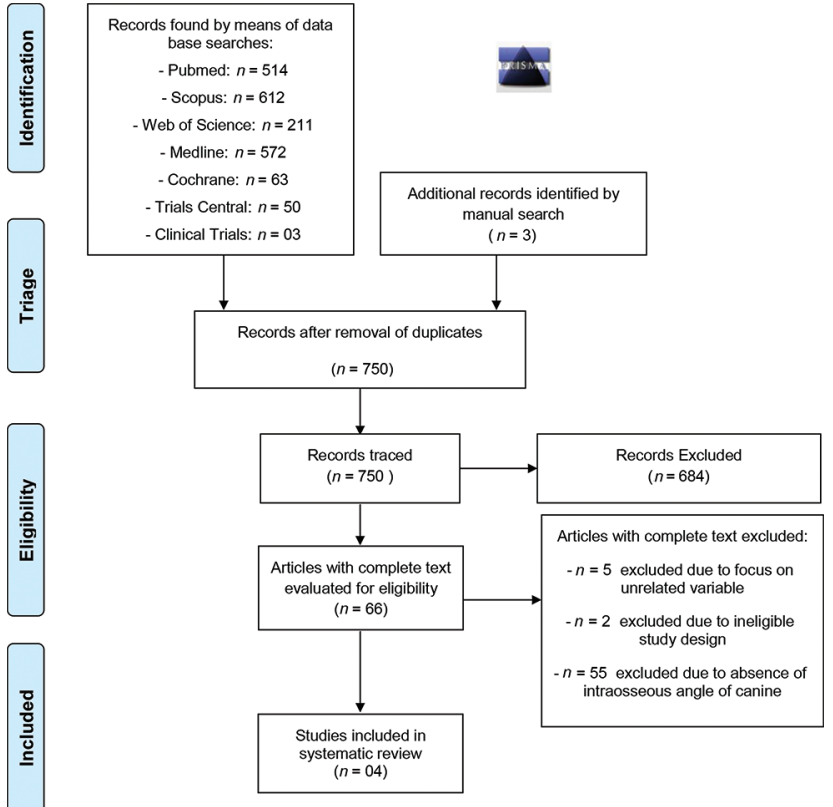

Fig. 1 Flow diagram showing evidence of synthesis of systematic review in accordance with preferred reporting items for systematic review and meta-analysis (PRISMA) guidelines

As control, two ${ }^{3,13}$ studies made paired evaluations of patients with BCLP, one ${ }^{13}$ study used the analysis of Bergland for the graft, and both ${ }^{3,13}$ used predefined angulation for the canine, and the split mouth system for the patients with UCLP.,13Two other studies ${ }^{7,14}$ used the split mouth system for all the patients with UCLP.

\section{Risk of Bias}

$\mathrm{All}^{3,7,13,14}$ the studies showed serious risk of bias due to confounding factors, and two ${ }^{13,14}$ studies had serious risk of bias due to missing data and bias in selection of the result reported. All $3,7,13,14$ the studies had critical risk of bias due to measurement of outcomes. The overall bias of studies ${ }^{3,7,13,14}$ was of critical risk (-Fig. 2). 
Table 3 Characteristics of studies included

\begin{tabular}{|c|c|c|c|c|}
\hline \multicolumn{5}{|c|}{ Study design, description of participants, and interventions included } \\
\hline Study/year & Meazzini et al $^{13}$ & Russell et $\mathrm{al}^{3}$ & Westerlund et al ${ }^{14}$ & Holz et $\mathrm{al}^{7}$ \\
\hline Sample size (F/M) & 116 & 101 & $68(19 / 49)$ & $75(24 / 51)$ \\
\hline UCLP/BCLP & 87 UCLP/29 BCLP & 53 UCLP/48 BCLP & 68 UCLP & 75 UCLP \\
\hline $\begin{array}{l}\text { Age of participants (min/ } \\
\text { max) }\end{array}$ & $9.8 \pm 4$ y $(4 y-20 y)$ & $\begin{array}{l}7 y \text { - early graft }(5 y-8 y 9 m) \\
13 y 7 m \text { - late graft }(9 y 3 m- \\
16 y 9 m)\end{array}$ & $7 y(6 y-8 y)$ & $9.8 \pm 0.7 y$ \\
\hline $\begin{array}{l}\text { Evaluation Method: } \\
\text { grafts/canine }\end{array}$ & $\begin{array}{l}\text { Bergland (Type I, } \\
\text { II, III, IV) / Types: } \\
1\left(<15^{\circ}\right), 2\left(15-45^{\circ}\right) \\
\text { and } 3\left(>45^{\circ}\right) \text { in } \\
\text { relation to OP }\end{array}$ & $\begin{array}{l}\text { NR/vertical position: normal } \\
\left(<45^{\circ}\right) \text {, at risk }\left(>45^{\circ}\right) \text { in } \\
\text { relation to MSP of } 90^{\circ} ; \\
\text { Lateral: normal (distal } \\
\text { position), at risk (mesial } \\
\text { position) to midplane of root } \\
\text { of LI }\end{array}$ & $\begin{array}{l}\text { NR/angulation of } \\
\text { canine: intersection of } \\
\text { its long axis with the } \\
\text { MSP }\end{array}$ & $\begin{array}{l}\mathrm{NR} / \text { mesiodistal } \\
\text { angulation: intersection } \\
\text { between its long axis and } \\
\text { the bicondylar line; Height } \\
\text { of canine: tip of cusp } \\
\text { perpendicular to OP }\end{array}$ \\
\hline $\begin{array}{l}\text { Prior Condition: Graft / } \\
\text { Canine }\end{array}$ & $\begin{array}{l}\text { Type I (71.7\%); II } \\
\text { (23.5\%); III (4.8\%); } \\
\text { IV (0\%) / Type 1 } \\
\text { (37.5\%); } 2 \text { (56.9\%); } \\
3 \text { (5.6\%) }\end{array}$ & $\begin{array}{l}\text { NR/early graft: abnormal } \\
\text { vertical position } 58 \% \text { and } \\
\text { abnormal lateral } 19 \% \text {; } \\
\text { Late graft: abnormal vertical } \\
\text { position } 48 \% \text { and abnormal } \\
\text { lateral 13\%. }\end{array}$ & $\begin{array}{l}\text { NR/impacted canine } \\
20.6 \% \text {; angulation of } \\
\text { canine cleft side: } 27^{0} \\
\text { and noncleft side: } 15.6^{0} \\
(p=0.001) \\
\text { Cleft side: pre-eruptive } \\
\text { angle of impacted } \\
\text { canines } 34.4^{0} \text { and in } \\
\text { spontaneous eruption } \\
25.5^{0}(p<0.05)\end{array}$ & $\begin{array}{l}\text { NR/(T1) late mixed } \\
\text { dentition: canine with } \\
\text { 1/4-2/3 of root before } \\
\text { graft placement; } \\
\text { Cleft side: angulation t1 } \\
\left(67.85^{\circ}\right) \text {; height } \\
\text { T1 }(-11.58 \mathrm{~mm}) \text {; } \\
\text { Noncleft side: angulation } \\
\text { T1 }\left(79.48^{\circ}\right) ; \text { height T1 } \\
(-7.74 \mathrm{~mm}) ;\end{array}$ \\
\hline Presence of $\mathrm{LI}$ & $\begin{array}{l}\text { Ll Absent: } \\
\text { (116P): 49.6\% } \\
\text { UCLP (87P): } 50.6 \% \\
\text { BCLP (29P): } 46.5 \%\end{array}$ & $\begin{array}{l}\text { LI Absent: Canine in } \\
\text { abnormal vertical position } \\
72 \% \text { and abnormal Lateral } \\
22 \% \text {; } \\
\text { LI present: Canine in } \\
\text { abnormal vertical position } \\
43 \% \text { and abnormal lateral } \\
26 \% \text {. }\end{array}$ & $\begin{array}{l}\text { LI absent on cleft side: } \\
48.5 \% \text { and noncleft } \\
\text { side: } 4.4 \%\end{array}$ & Absence LI reported \\
\hline $\begin{array}{l}\text { Intervention bone } \\
\text { graft; Age (variation) / } \\
\text { Orthodontics }\end{array}$ & $\begin{array}{l}\text { Gingival } \\
\text { alveoloplasty; } 33.9 \\
\mathrm{~m}(18 \text { to } 63 \mathrm{~m}) / \mathrm{NR}\end{array}$ & $\begin{array}{l}\text { lliac crest; Early graft < or }=9 \mathrm{y} \text {; } \\
\text { Late graft }>9 \mathrm{y} / \text { without } \\
\text { orthodontic treatment }\end{array}$ & $\begin{array}{l}\mathrm{NR} / 7 \mathrm{y}(6 \mathrm{y}-8 \mathrm{y}) / \\
\text { orthodontic treatment } \\
\text { performed }\end{array}$ & $\begin{array}{l}\text { Graft with rhBMP-2/ } \\
9.8 \pm 0,7 y \text { / Orthodontic } \\
\text { treatment: } 90 \% \text { RME before } \\
\text { performing graft (T1) }\end{array}$ \\
\hline Control & $\begin{array}{l}\text { Paired evaluation } \\
\text { (BCLP) and } \\
\text { nonoperated Side } \\
\text { (UCLP) }\end{array}$ & $\begin{array}{l}\text { Paired evaluation (BCLP) and } \\
\text { nonoperated side (UCLP) }\end{array}$ & Nonoperated side & Nonoperated side \\
\hline
\end{tabular}

Abbreviations: BCLP, unilateral cleft lip and palate; F, Female; LI, lateral incisor; M, male; Max, maximum; Min, minimum; MSP, median sagittal plane; NR, not reported; OP, occlusal plane; RME, rapid maxillary expansion; UCLP, unilateral cleft lip and palate.

\section{Results of Studies Included}

\section{Increased Rate of Canine Eruption}

The SoF in -Table 5 describes the outcomes and the certainty of the evidence using GRADE approach for narrative synthesis. All the studies ${ }^{3,7,13,14}$ reported improvement in angulation of the canine after bone grafting, which favored canine eruption ( - Tables $3-4$ ), with very low certainty of evidence ( - Table 5 ). In a prior manner, the angulation of canine eruption before bone graft surgery was considered a risk for impaction by all ${ }^{3,7,13,14}$ the studies, and only one ${ }^{7}$ study clearly described the stage of root formation in $1 / 4$ to $2 / 3$ of the root of the canine on the cleft side before the bone graft.

One ${ }^{13}$ study reported that the rate of canine eruption was strongly correlated with its previous inclination (Fisher, $p<0.00$ ); the angulation of the canine on the noncleft side ranged from $15.9^{0}(p<0.001)^{14}$ to $86.6^{0}(p<0.001),{ }^{7}$ values with significant difference in relation to the cleft side. Canine impaction on the noncleft side ranged from $1.3 \%\left(86.6^{0}\right)(p<0.001)^{7}$ and $2.9 \%\left(30^{\circ}\right)(p<0.05)^{14}$ to $25 \%\left(>45^{0}\right) .^{3}$ One $^{13}$ study did not clearly report about the frequency of canine impaction on the noncleft side. Only one ${ }^{14}$ study clearly reported that canine impaction increased by $50 \%$ after reoperation of the bone graft.

\section{Success of Bone Graft}

In general, all ${ }^{3,7,13,14}$ the studies reported success of the bone graft ( - Table 4) with low certainty of evidence ( - Table 5 ). After follow-up, the condition of the graft was considered a success in all the individuals in $\mathrm{two}^{3,7}$ studies, and successful in $93.7 \%$ of patients in one ${ }^{13}$ study. Only two ${ }^{13,14}$ studies reported rates of bone graft failures; however, the rates were low, $11.8 \%{ }^{14}$ and $6.3 \%,{ }^{13}$ indicating that bone grafting procedures were successful in the large majority of cases. 
All ${ }^{3,113,14}$ the studies performed 2D radiographic follow-up examinations, with initial and final panoramic $r-X$ examinations; however, with wide sample ${ }^{13,14}$ and temporal variation in ${ }^{3,7,13,14}$ the examinations performed. No study used 3D examinations. The initial and final $\mathrm{r}-\mathrm{X}$ examinations, respectively, were performed on an average at $4.9 \mathrm{y}$ and $12.5 \mathrm{y}$ (partial sample $=76),{ }^{13} 7 \mathrm{y}$ (partial sample $\left.=59\right)$ and $10 \mathrm{y}$ (partial sample $=41)^{14}, 6.2 \mathrm{y}$ and $8.10 \mathrm{y}$ (early graft) and $12.8 \mathrm{y}$ and $14.4 \mathrm{y}$ (late graft), ${ }^{3}$ and $9.8 \mathrm{y}$ (T1)-T2 (3-12 m after T1) and T3 $>13 \mathrm{~m}$ after T1 (mean time of follow-up 33m). ${ }^{7}$

\section{Canine Impacted due to Agenesis of the Lateral Incisor}

Three studies clearly reported canine impaction due to agenesis of the lateral incisor, with conflicting results. ${ }^{3,713} \mathrm{Two}^{3,7}$ studies reported association between the rate of canine impaction and agenesis of the lateral incisor, while another ${ }^{13}$ study did not find this association (-Tables $\mathbf{3}-\mathbf{4}$ ), with very low certainty of the evidence (-Table 5). Agenesis of the lateral incisor generated distinct canine impaction in the patients with UCLP, ranging from $72.2 \%,{ }^{7} 68 \%$ of the vertical position and/or abnormal lateral position ${ }^{3}$, of up to $20 \% .{ }^{13}$ Non impaction was 33.3\% $(p=0.006)$ in one ${ }^{7}$ study, and $80 \%$ in the other. ${ }^{13}$ One $^{3}$ study reported that the noncleft side also demonstrated some type of abnormal position of the canine, $54 \%$, vertical and/or lateral.

\section{Effect of Orthodontic Treatment before and after Bone Graft Surgery}

Two studies reported the effect of orthodontic treatment before and after the bone graft. ${ }^{7,13}$ In general, one ${ }^{7}$ study reported association between rapid maxillary expansion (RME) and gain of space in the maxilla and improved response of tooth eruption before the bone graft, while the other ${ }^{13}$ study did not obtain this association ( - Tables $3-4$ ), with very low certainty of the evidence ( - Table 5 ). In the pregraft period, only one ${ }^{7}$ study clearly reported the type of orthodontic treatment performed, which was RME in 90\% of the patients. In the postgraft period, one study ${ }^{13}$, with a

Table 4 Outcome of studies included

\begin{tabular}{|c|c|c|c|c|}
\hline \multicolumn{5}{|c|}{ Characteristics of interventions and details of outcomes } \\
\hline Study/year & Meazzini et al $^{13}$ & Russell et al $^{3}$ & Westerlund et al $^{14}$ & Holz et $\mathrm{al}^{7}$ \\
\hline $\begin{array}{l}\text { Radiographic } \\
\text { follow-up: time } \\
\text { interval(s); 2D, } \\
\text { 3D }\end{array}$ & $\begin{array}{l}\text { (76P): initial r-X: } 4.9 \\
\pm 1.8 y \text { and final r-X: } \\
12.5 \pm 4.9 \text { y; panoramic } \\
r-X\end{array}$ & $\begin{array}{l}\text { initial r-X: } 10 \text { m before } \\
\text { early graft, and } 11 \mathrm{~m} \\
\text { before late graft. } \\
\text { Post-graft r-X: } 2 \text { y } 8 \mathrm{~m} \\
\text { after early graft, and } 1 \\
\text { y } 8 \text { m after late graft; } \\
\text { panoramic r-X }\end{array}$ & $\begin{array}{l}\text { initial r-X (59P): } 7 \text { y }(6 \text { y-8 } \\
\text { y); final r-X (41P): } 10 \text { y } \\
\text { (9y-11y); in both time inter- } \\
\text { vals (32P)/panoramic r-X }\end{array}$ & $\begin{array}{l}\mathrm{r}-\mathrm{X} \text { : before (T1), 3-12 m } \\
\text { postgraft (T2), > } 13 \mathrm{~m} \\
\text { postgraft (T3)/panoramic r-X/ } \\
\text { mean time of follow-up: } 33 \mathrm{~m}\end{array}$ \\
\hline $\begin{array}{l}\text { Condition of } \\
\text { graft }\end{array}$ & $\begin{array}{l}\text { Unchanged 68.4\%; } \\
\text { Improved 25.3\%; } \\
\text { Worsened 6.3\% }\end{array}$ & Success & Failure $11.8 \%$ & Success \\
\hline $\begin{array}{l}\text { Position of } \\
\text { canine (rate of } \\
\text { eruption) }\end{array}$ & $\begin{array}{l}\text { Unchanged 36,8\%; } \\
\text { Improved 40\%; } \\
\text { Worsened 23.2\% (45P } \\
\text { permanent dentition- } \\
\text { UCLP: 80\% eruption; } \\
\text { 15.5\% retention; } 4.5 \% \\
\text { surgical exposure) } \\
\text { Eruption was strongly } \\
\text { correlated with the } \\
\text { previous inclination } \\
\text { (Fisher, } p<0.00 \text { ) }\end{array}$ & $\begin{array}{l}\text { Early graft: abnormal } \\
\text { vertical position } 44 \% \text { and } \\
\text { abnormal lateral } 28 \% \text {; } \\
\text { Late graft: abnormal } \\
\text { vertical position } 13 \% \text { and } \\
\text { abnormal lateral } 30 \% \text {. }\end{array}$ & $\begin{array}{l}\text { Angulation: Cleft side } 31.9^{0} \\
\text { and noncleft side } 15.9^{0} \\
\text { ( } p<0.001) \text {; } \\
\text { Pre-eruptive angulation on } \\
\text { cleft side: } 38.7^{\circ} \text { (impacted } \\
\text { canines) and } 30^{\circ} \text { (spontane- } \\
\text { ous eruption) }(p<0.05) ; \\
\text { Impacted canines: cleft side } \\
17.6 \% \text { and noncleft side } \\
2.9 \% \text {; impaction ( } \uparrow 50 \%) \\
\text { with reoperation of the graft } \\
\text { (mean: } 12 \text { y) }\end{array}$ & $\begin{array}{l}\text { Cleft side: } \\
\text { angulation T2 }\left(65.62^{\circ}\right) \mathrm{T} 3 \\
\left(74.42^{\circ}\right)(p<0.001) \text {; height T2 } \\
(-7.05 \mathrm{~mm}) \mathrm{T} 3(-1.67 \mathrm{~mm}) \\
(p<0.001) ; \mathrm{T} 3: \text { impaction } \\
\text { (24\%) and eruption }(76 \%) \\
\text { Noncleft side: } \\
\text { angulation T2 }\left(82.63^{0}\right) \mathrm{T} 3 \\
\left(86.62^{\circ}\right)(p<0.001) \text {; height: } \\
\text { T2 }(-2.63 \mathrm{~mm}) \mathrm{T} 3(-1.92 \mathrm{~mm}) \\
(p<0.001) ; \text { T3: Impaction } \\
(1.3 \%) \text { and eruption }(98.7 \%)\end{array}$ \\
\hline $\begin{array}{l}\text { Position of } \\
\text { canine versus LI }\end{array}$ & $\begin{array}{l}\text { Subgroup 45P UCLP: } \\
\text { 36P canine erupted (LI } \\
\text { absent: } 55.5 \% \text { and LI } \\
\text { present: } 44.4 \%) ; \\
\text { 7P canine retained (LI } \\
\text { absent: } 42,8 \% \text { and LI } \\
\text { present: } 57.1 \% \text { ); } \\
\text { 2P surgical exposure } \\
\text { (LI absent: } 100 \% \text { and LI } \\
\text { present: } 0 \% \text { ); }\end{array}$ & $\begin{array}{l}\text { LI absent: abnormal } \\
\text { vertical position } 36 \% \text { and } \\
\text { abnormal lateral } 32 \% \text {. } \\
\text { LI present: abnormal } \\
\text { vertical position } 36 \% \text { and } \\
\text { abnormal lateral } 18 \% \text {. }\end{array}$ & NR & $\begin{array}{l}\text { LI Absent: impaction of canine } \\
(72.2 \%) \text { and nonimpaction } \\
(33.3 \%)(p=0.006)\end{array}$ \\
\hline $\begin{array}{l}\text { Postgraft } \\
\text { orthodontic } \\
\text { treatment /type } \\
\text { and time }\end{array}$ & $\begin{array}{l}\text { Subgroup 45P } \\
\text { Permanent dentition, } \\
\text { UCLP: } 100 \% \text { of ortho- } \\
\text { dontic treatment, } 70 \% \\
\text { underwent orthopedic } \\
\text { expansion/NR }\end{array}$ & NR & $\begin{array}{l}\text { Orthodontic treatment } \\
\text { performed/NR }\end{array}$ & $\begin{array}{l}\text { (T2) without orthodontic } \\
\text { treatment, (T3) } 28 \% \text { fixed } \\
\text { partial orthodontic treatment } \\
\text { for correction of LI rotation }\end{array}$ \\
\hline
\end{tabular}


Table 4 (continued)

\begin{tabular}{|c|c|c|c|c|}
\hline \multicolumn{5}{|c|}{ Characteristics of interventions and details of outcomes } \\
\hline Study/year & Meazzini et al $^{13}$ & Russell et al $^{3}$ & Westerlund et al ${ }^{14}$ & Holz et al ${ }^{7}$ \\
\hline Conclusion & $\begin{array}{l}\text { Early secondary gingival } \\
\text { alveoloplasty appeared } \\
\text { to allow adequate } \\
\text { ossification in both } \\
\text { the nasal and alveolar } \\
\text { regions. Permanent } \\
\text { tooth eruption } \\
\text { occurred at a normal } \\
\text { rate. Early secondary } \\
\text { gingival alveoloplasty } \\
\text { may be adopted to } \\
\text { reduce the number of } \\
\text { surgical interventions } \\
\text { (without the need for } \\
\text { secondary bone graft) } \\
\text { without the need for } \\
\text { invasive pre-surgical } \\
\text { orthopedic treatment. } \\
\text { To the contrary, } \\
\text { patients submitted to } \\
\text { early secondary gingival } \\
\text { alveoloplasty appeared } \\
\text { to exhibit a higher } \\
\text { incidence of canine } \\
\text { retention and need for } \\
\text { orthopedic maxillary } \\
\text { expansion. }\end{array}$ & $\begin{array}{l}\text { Patients with complete } \\
\text { alveolar clefts had a } \\
\text { significantly changed } \\
\text { canine position during } \\
\text { eruption and had an } \\
\text { increased risk of canine } \\
\text { impaction in comparison } \\
\text { with a population of } \\
\text { patients without clefts. } \\
\text { Both the time of bone } \\
\text { grafting and presence } \\
\text { of lateral incisors were } \\
\text { factors capable of } \\
\text { influencing the risk } \\
\text { of canine impaction. } \\
\text { Bone grafting must be } \\
\text { planned in accordance } \\
\text { with maxillofacial and } \\
\text { dental development, } \\
\text { considering the eruption } \\
\text { and periodontal health } \\
\text { of the teeth adjacent to } \\
\text { the cleft. }\end{array}$ & $\begin{array}{l}\text { The prevalence of impac- } \\
\text { tion was ten times higher } \\
\text { in comparison with that } \\
\text { in the general population. } \\
\text { The factors associated with } \\
\text { canine impaction are a } \\
\text { pre-eruptive inclination of } \\
>30^{\circ} \text { and re-operation of the } \\
\text { bone transplant. }\end{array}$ & $\begin{array}{l}\text { The risks of canine impaction } \\
\text { on the cleft side in patients } \\
\text { with UCLP are associated with } \\
\text { the increase in mesiodistal } \\
\text { inclination }\left(\leq 68^{\circ}\right) \text {. Agenesis of } \\
\text { the maxillary lateral incisor on } \\
\text { the cleft side is an indicator of } \\
\text { early risk for canine impac- } \\
\text { tion. Mesial displacement and } \\
\text { superimposition on neighbor- } \\
\text { ing incisors could not clearly } \\
\text { predict impaction on the cleft } \\
\text { side in patients with UCLP. }\end{array}$ \\
\hline
\end{tabular}

Abbreviations: LI, lateral incisor; NR, not reported; P, patients; UCLP, unilateral cleft lip and palate.

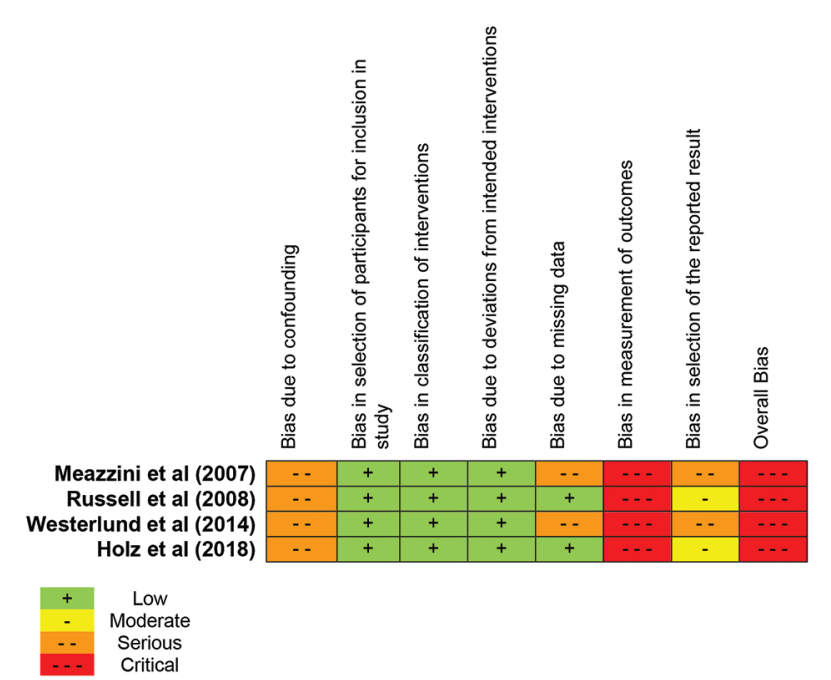

Fig. 2 Risk of bias through risk of bias in nonrandomized studies of interventions (ROBINS-I).

subgroup of 45 patients at the stage of permanent dentition were treated with orthodontic movement and $70 \%$ of the patients were submitted to RME. In another study ${ }^{7}, 28 \%$ of the patients were submitted to orthodontic treatment with partial fixed appliances for rotational correction of the lateral incisor. In both studies, the treatments were performed after the period of canine eruption. ${ }^{7,13}$

\section{Certainty of the Evidence}

The certainty of the evidence was very low or low due to problems of risk of bias, inconsistency, indirectness, imprecision, and publication bias ( $\mathbf{- T a b l e} \mathbf{5}$ ). The evidence was rated up due to large effect.

\section{Discussion}

There was very low evidence of patients with cleft lip and palate being able to benefit from bone graft surgery for eruption of the canine teeth.

With regard to the outcome, involving successful bone graft, different types of grafts were reported, which contributed to the heterogeneity of the estimates. The rhBMP-2 (morphogenetic bone proteins) were used in one ${ }^{7}$ study and may have influenced bone healing ${ }^{7,21}$ and favored tooth eruption. Complications such as reoperation procedures performed due to failure of the bone grafts reported ${ }^{13,14}$ elevated the risk of canine impaction, due to the additional surgery that deteriorated a site that was already overloaded with inherited and environmental limitations ${ }^{14}$. Although the studies ${ }^{3,7,13,14}$ reported successful bone grafting and tooth eruption with panoramic radiography, ${ }^{22}$ there was wide methodological variability of the studies and potential influence of the evaluator on the results. In this sense, 3D analyses must be encouraged as a method for evaluating the results of canine eruption, and recently-formed bone ${ }^{23} 6$ months post-surgery with cortical bone maturation. ${ }^{24}$ 
Table 5 Summary of findings (SoF) table according to the grades of recommendations, assessment, development, and evaluation (GRADE) approach to narrative synthesis

\begin{tabular}{|c|c|c|c|c|c|c|c|c|c|}
\hline \multicolumn{10}{|c|}{ Certainty assessment } \\
\hline $\begin{array}{l}\text { N. of } \\
\text { stud- } \\
\text { ies }\end{array}$ & $\begin{array}{l}\text { Study } \\
\text { design }\end{array}$ & $\begin{array}{l}\text { Risk } \\
\text { of } \\
\text { bias }\end{array}$ & Inconsistency & Indirectness & Imprecision & $\begin{array}{l}\text { Publication } \\
\text { bias }\end{array}$ & $\begin{array}{l}\text { Other fac- } \\
\text { tors: great } \\
\text { magnitude } \\
\text { effect }\end{array}$ & Impact & Certainty \\
\hline \multicolumn{10}{|c|}{ Increased rate of canine eruption } \\
\hline $4^{\mathrm{a}}$ & NRCTs & $\begin{array}{l}\text { Very } \\
\text { seri- } \\
\text { ous }^{d}\end{array}$ & Not serious & Not serious & Not serious & $\begin{array}{l}\text { Strongly } \\
\text { suspected }\end{array}$ & $\begin{array}{l}\text { Large } \\
\text { effect }^{i}\end{array}$ & $\begin{array}{l}\text { All studies reported asso- } \\
\text { ciation between increase } \\
\text { in rate of tooth eruption } \\
\text { and bone graft. The } \\
\text { individuals who received } \\
\text { bone grafts before canine } \\
\text { eruption had less experi- } \\
\text { ence of tooth impaction }\end{array}$ & Very low \\
\hline \multicolumn{10}{|c|}{ Successful bone graft } \\
\hline $4^{\mathrm{a}}$ & NRCTs & $\begin{array}{l}\text { Very } \\
\text { seri- } \\
\text { ous }^{\mathrm{d}}\end{array}$ & Not serious & Not serious & Not serious & \begin{tabular}{|l|} 
Strongly \\
suspected
\end{tabular} & $\begin{array}{l}\text { Very large } \\
\text { effect }^{i}\end{array}$ & \begin{tabular}{|l|} 
All studies reported \\
greater experience of \\
successful surgery. Two \\
studies experienced \\
unsuccessful surgery with \\
need for reoperation
\end{tabular} & Low \\
\hline \multicolumn{10}{|c|}{ Canine impacted due to agenesis of the lateral incisor } \\
\hline $3^{b}$ & NRCTs & $\begin{array}{l}\text { Very } \\
\text { seri- } \\
\text { ous }^{d}\end{array}$ & Very serious e & Not serious & Serious ${ }^{g}$ & \begin{tabular}{|l|} 
Strongly \\
suspected
\end{tabular} & $\begin{array}{l}\text { Large } \\
\text { effect }^{i}\end{array}$ & $\begin{array}{l}\text { The majority of the } \\
\text { studies ( } 2 \text { out of } 3 \text { ) found } \\
\text { association between the } \\
\text { rate of canine impaction } \\
\text { and agenesis of the } \\
\text { lateral incisor. One study } \\
\text { found that agenesis was } \\
\text { not associated with tooth } \\
\text { impaction }\end{array}$ & Very low \\
\hline \multicolumn{10}{|c|}{ Effect of orthodontic treatment before and after bone graft surgery } \\
\hline $2^{c}$ & NRCTs & $\begin{array}{l}\text { Very } \\
\text { seri- } \\
\text { ous }^{\mathrm{d}}\end{array}$ & Very serious ${ }^{\mathrm{e}}$ & Serious ${ }^{f}$ & Serious ${ }^{9}$ & $\begin{array}{l}\text { Strongly } \\
\text { suspected h }\end{array}$ & $\begin{array}{l}\text { Large } \\
\text { effect }^{i}\end{array}$ & \begin{tabular}{|l|} 
One study found that \\
individuals submitted to \\
RME before bone graft \\
had greater gain of space \\
in the maxilla and better \\
response of tooth erup- \\
tion. One study reporter \\
higher level of experience \\
of gain in space of the \\
maxilla and response \\
of tooth eruption with \\
postgraft RME
\end{tabular} & Very low \\
\hline
\end{tabular}

Abbreviations: NRCTs, nonrandomized controlled trials; RME, rapid maxillary expansion.

4 studies: $3,7,13,14$.

b 3 studies: $3,7,13$.

'2 study: 7.13.

${ }^{\mathrm{d}}$ All the studies included showed risk of bias; they were NRCTs with great problems in relation to the effect of confounders, selection of participants, lack of blinding, reproducibility, and bias in selection of the result.

eThere was inconsistency in the estimates of the studies: two estimates were more in favor of eruption with agenesis and 1 estimative favored impaction with agenesis. One estimate favored RME before bone grafting.

${ }^{\mathrm{f}}$ The evidence came from studies with only two types of orthodontic treatments that were applicable to cleft lip and palate, limiting the applicability to other orthodontic treatments.

${ }^{9}$ Based on the ideal size of the information (OIS), the number of events was lower than 300 for the dichotomous variable.

hSuspicion of publication bias due to possible estimates not published which may not have been statistically significant.

The outcomes demonstrated the effect of great magnitude for the estimates: large RR 50\% and very large RR $80 \%$.

The 3D examination may increase the interexaminer reliability, improve reproducibility of the method $^{25}$, enable digitization of small regions for precise diagnosis, and have low dose irradiated in reduced images ${ }^{26}$ of the cleft.
Cleft lip and palate arise from the absence of fusion between the primary palate, secondary uni- or bilateral maxillary and palatine processes, affect the upper lip and extend up to the sulcus between the canine and lateral incisor 
(LI), commonly generating agenesis and tooth impactions, even attaining the maxilla and nose in the eighth week of gestation. ${ }^{3,27}$ As from this gestational phase, absence of the LI over the course of time appears to be a factor that reduces the potential of verticalization of the canines and spontaneous eruption, ${ }^{3,14}$ with $68 \%$ more risk of impaction versus $6 \%$ on the noncleft side ${ }^{3}$, and predictive of impaction in $81 \%$ of the individuals. ${ }^{7}$ For other ${ }^{13,27}$ studies, the presence of LI did not appear to be so relevant in the orientation of canine eruption.

In the outcome, rate of canine eruption, mesiodistal inclination appeared to be predictive of canine retention. ${ }^{13}$ Some studies have suggested that mesiodistal inclination of the canine $>30^{\circ}$ in 7 to 10 years may increase the probability of impaction, $3,14,27,28$ when compared with the medium angle of $22^{\circ 29}$ of impacted canines in patients without clefts. Although other authors ${ }^{30}$ have not found this association, in the studies evaluated, the cleft side showed canines that were more angulated ${ }^{3,7,13,14}$ and more distant from the occlusal plane? ${ }^{7}$. In the postgraft period, the position of the canine became more vertical in the majority of the individual $s^{3,7,13,14}$ and the neoformed bone frequently allowed spontaneous migration and eruption of the canine on the cleft side. ${ }^{7,31-33}$ The studies ${ }^{3,7,13,14}$ were not sufficiently clear about whether the follow-up of the canine corresponded to the period of rhizogenesis and active eruption, commonly occurring from 9 to 12 years; and only two studies reported follow-up for periods longer than 36 months. ${ }^{13,14}$

The outcome, orthodontic treatment success, combined orthodontics with the surgical approaches as a common procedure in UCLP and BCLP. Along this line, expansion of the maxillary arch before bone grafting has been recommended in many clinical discussions, but not supported in the literature as being necessary to increase the space in the area of the cleft and promote canine eruption. ${ }^{3}$ Only one ${ }^{7}$ study was clear about the orthodontic treatment performed prior to bone grafting, RME in $90 \%$ of the individuals. As an alternative approach, post bone-grafting expansion would minimize the size of the cleft defect. Two ${ }^{3,13}$ studies considered postbone grafting the adequate time for performing the two treatments, using maxillary expansion and fixed orthodontic appliances. To sum up, it was not sufficiently clear whether there would be a significant difference in canine eruption if expansion of the arch were performed pre- or postbone grafting. ${ }^{31,32}$ Although this study addressed as comparison (C) in PICO question the side not submitted to surgery for patients with UCLP, the descriptive results demonstrated for BCLP suggest a behavior similar to the cleft side of patients with UCLP, with analogous outcomes.

The certainty of the evidence was low to very low. In general, all studies had critical risk of bias, due to confunding, bias on account of missing data, bias in measurement of the outcome and selection of the result reported. There was imprecision for some outcomes due to limited number of studies and this consequently limited the sample size and number of events. We also found inconsistency in results with conflicting data and limited applicability of the types of orthodontic treatments that could improve the rates of canine eruption. Although we thoroughly searched several electronic databases, gray literature and performed a manual search, we suspected a selection reporting bias in trials that did not publishing negative outcomes. We rated up the certainty of the evidence, since some studies reported effect estimates of large effect.

\section{Strengths and Limitations}

This study had limitations. There were a limited number of studies included, which led to the effect of imprecision of the data input on the results. Meta-analysis was not possible due to the great heterogeneity of data reported among studies. However, as a strong point, we used the GRADE approach to report the certainty of the evidence for narrative synthesis when ROBINS-I was used for risk of bias. ${ }^{19}$ The GRADE approach for narrative synthesis can avoid misleading conclusions and be more conservative for interpretation of the results. ${ }^{19,34}$ This systematic view was conducted with strict methodological rigor.

\section{Implications for Research}

Controlled clinical trials (RCTs) with clinical and radiographic methodologies such as standardization of the severity of the cleft, blinding of the professionals (the outcome evaluator should not be the surgeon, and should not have knowledge of the patient's previous history), performing sample calculation, evaluating the level of rhizogenesis of the canine, and time of follow-up longer than 3 years, in order to evaluate the influence of bone grafting and agenesis of the lateral incisor on the eruption of the canine, are necessary and would offer more information in the long term. However, due to the particularities of patients with cleft lip and palate, factors such as age, patient expectations, surgical options, and orthodontic planning may make it difficult to conduct RCTs. Therefore, future high-quality, nonrandomized observational studies may allow significant outcomes to be obtained.

Possible sources of bias must be controlled, such as the insertion of sufficiently clear protocols for surgical and orthodontic treatment, 3D measurement instruments of recently-formed bone and tooth eruption, and longer periods of follow-up. Further studies must also investigate the esthetic satisfaction and quality of life of patients submitted to the different treatment modalities.

\section{Conclusions}

There is low to very low certainty of evidence:

- Of the efficacy of the secondary bone graft for patients with cleft lip and palate.

- Secondary alveolar bone grafting favored the increase in rates of eruption and diminished impaction of maxillary canines.

- On the effect of grafting on the rate of canine impaction and agenesis of the lateral incisor.

- On the efficacy of orthodontic treatment before bone grafting to promote greater gain of space in the maxilla and improve the response of tooth eruption.

\section{Conflict of Interest}

None declared. 


\section{Acknowledgment}

Acknowledgment for the Scientific Initiation Scholarships of the PIBIC and VIC Programs (CNPq/UFJF).

\section{References}

1 Park HM, Han DH, Baek SH. Comparison of tooth development stage of the maxillary anterior teeth before and after secondary alveolar bone graft: Unilateral cleft lip and alveolus vs unilateral cleft lip and palate. Angle Orthod 2014;84(6):989-994

2 Liao YF, Huang CS. Presurgical and postsurgical orthodontics are associated with superior secondary alveolar bone grafting outcomes. J Craniomaxillofac Surg 2015;43(5):717-723

3 Russell KA, McLeod CE. Canine eruption in patients with complete cleft lip and palate. Cleft Palate Craniofac J 2008;45(1):73-80

4 Souza J, Raskin S. Clinical and epidemiological study of orofacial clefts. J Pediatr (Rio J) 2013;89(2):137-144

5 Collins M, James DR, Mars M. Alveolar bone grafting: a review of 115 patients. Eur J Orthod 1998;20(2):115-120

6 Jia YL, Fu MK, Ma L. Long-term outcome of secondary alveolar bone grafting in patients with various types of cleft. Br J Oral Maxillofac Surg 2006;44(4):308-312

7 Simões Holz I, Martinelli Carvalho R, Lauris JR, Lindauer SJ, Gamba Garib D. Permanent canine eruption into the alveolar cleft region after secondary alveolar bone grafting: Are there prediction factors for impaction? Am J Orthod Dentofacial Orthop 2018;154(5):657-663

8 Schultze-Mosgau S, Nkenke E, Schlegel AK, Hirschfelder U, Wiltfang J. Analysis of bone resorption after secondary alveolar cleft bone grafts before and after canine eruption in connection with orthodontic gap closure or prosthodontic treatment. J Oral Maxillofac Surg 2003;61(11):1245-1248

9 Enemark H, Sindet-Pedersen S, Bundgaard M. Long-term results after secondary bone grafting of alveolar clefts. J Oral Maxillofac Surg 1987;45(11):913-919

10 Hardesty RA, Marsh JL. Craniofacial onlay bone grafting: a prospective evaluation of graft morphology, orientation, and embryonic origin. Plast Reconstr Surg 1990;85(1):5-14, discussion 15

11 Enemark H, Jensen J, Bosch C. Mandibular bone graft material for reconstruction of alveolar cleft defects: long-term results. Cleft Palate Craniofac J 2001;38(2):155-163

12 Kortebein MJ, Nelson CL, Sadove AM. Retrospective analysis of 135 secondary alveolar cleft grafts using iliac or calvarial bone. J Oral Maxillofac Surg 1991;49(5):493-498

13 Meazzini MC, Tortora C, Morabito A, Garattini G, Brusati R. Alveolar bone formation in patients with unilateral and bilateral cleft lip and palate after early secondary gingivoalveoloplasty: Long-term results. Plast Reconstr Surg 2007;119(5):1527-1537

14 Westerlund A, Sjöström M, Björnström L, Ransjö M. What factors are associated with impacted canines in cleft patients? J Oral Maxillofac Surg 2014;72(11):2109-2114

15 Lacerda-Santos R, Canutto RF, Araújo JLDS, et al. Effect of orthodontic treatment on tooth autotransplantation: systematic review of controlled clinical trials. Eur J Dent 2020;14(3):467-482

16 Lacerda-Santos R, Bravin TC, Carvalho FG, Pithon MM, Lima ABL, da Silva KG. Efficacy of topical anesthetics in pain perception during mini-implant insertion: Systematic review of controlled clinical trials. Anesth Prog 2019;66(3):119-132

17 Pithon MM, Sant'Anna LI, Baião FC, dos Santos RL, Coqueiro RdaS, Maia LC. Assessment of the effectiveness of mouthwashes in reducing cariogenic biofilm in orthodontic patients: A systematic review. J Dent 2015;43(3):297-308
18 Sterne JA, Hernán MA, Reeves BC, et al. ROBINS-I: A tool for assessing risk of bias in non-randomised studies of interventions. BMJ 2016;355:i4919

19 Murad MH, Mustafa RA, Schünemann HJ, Sultan S, Santesso N. Rating the certainty in evidence in the absence of a single estimate of effect. Evid Based Med 2017;22(3):85-87

20 Schünemann HJ, Cuello C, Akl EA, et al; GRADE Working Group. GRADE guidelines: 18. How ROBINS-I and other tools to assess risk of bias in nonrandomized studies should be used to rate the certainty of a body of evidence. J Clin Epidemiol 2019;111(4):105-114

21 Bedouelle JI. Induction osseuse-Réparation osseuse. Protéine osseuse morphogénétique humaine recombinante (rh BMP) Rev Chir Orthop Repar Appar Mot 1994;80(3):165-168

22 Zechner W, Watzak G, Gahleitner A, Busenlechner D, Tepper G, Watzek G. Rotational panoramic versus intraoral rectangular radiographs for evaluation of peri-implant bone loss in the anterior atrophic mandible. Int J Oral Maxillofac Implants 2003;18(6):873-878

23 Stasiak M, Wojtaszek-Słomińska A, Racka-Pilszak B. Current methods for secondary alveolar bone grafting assessment in cleft lip and palate patients - A systematic review. J Craniomaxillofac Surg 2019;47(4):578-585

24 Thuaksuban N, Nuntanaranont T, Pripatnanont P. A comparison of autogenous bone graft combined with deproteinized bovine bone and autogenous bone graft alone for treatment of alveolar cleft. Int J Oral Maxillofac Surg 2010;39(12):1175-1180

25 Eslami E, Barkhordar H, Abramovitch K, Kim J, Masoud MI. Cone-beam computed tomography vs conventional radiography in visualization of maxillary impacted-canine localization: A systematic review of comparative studies. Am J Orthod Dentofacial Orthop 2017;151(2):248-258

26 Scarfe WC, Farman AG, Sukovic P. Clinical applications of cone-beam computed tomography in dental practice. J Can Dent Assoc 2006;72(1):75-80

27 Tortora C, Meazzini MC, Garattini G, Brusati R. Prevalence of abnormalities in dental structure, position, and eruption pattern in a population of unilateral and bilateral cleft lip and palate patients. Cleft Palate Craniofac J 2008;45(2):154-162

28 Power SM, Short MB. An investigation into the response of palatally displaced canines to the removal of deciduous canines and an assessment of factors contributing to favourable eruption. Br J Orthod 1993;20(3):215-223

29 Ericson S, Kurol J. Early treatment of palatally erupting maxillary canines by extraction of the primary canines. Eur J Orthod 1988;10(4):283-295

30 Warford JH Jr, Grandhi RK, Tira DE. Prediction of maxillary canine impaction using sectors and angular measurement. Am J Orthod Dentofacial Orthop 2003;124(6):651-655

31 da Silva Filho OG, Teles SG, Ozawa TO, Filho LC. Secondary bone graft and eruption of the permanent canine in patients with alveolar clefts: literature review and case report. Angle Orthod 2000;70(2):174-178

32 Hogan L, Shand JM, Heggie AA, Kilpatrick N. Canine eruption into grafted alveolar clefts: A retrospective study. Aust Dent J 2003;48(2):119-124

33 Oberoi S, Gill P, Chigurupati R, Hoffman WY, Hatcher DC, Vargervik K. Three-dimensional assessment of the eruption path of the canine in individuals with bone-grafted alveolar clefts using cone beam computed tomography. Cleft Palate Craniofac J 2010;47(5):507-512

34 Zhang Y, Akl EA, Schünemann HJ. Using systematic reviews in guideline development: the GRADE approach. Res Synth Methods 2018;10(3):312-329 